\title{
QUALITATIVE STUDY ON THE IMPLEMENTATION OF PUBLIC HEALTH NURSING: OBJECTIVE, RESOURCES, AND WORK PROCEDURE ON HOME CARE PATIENTS IN SURAKARTA
}

\author{
Ratih Novitasari1 ${ }^{1)}$, Rita Benya Adriani²), Eti Poncorini Pamungkasari3) \\ 1)Masters Program in Public Health, Sebelas Maret University \\ 2)School of Health Polytechnics, Surakarta \\ 3)Faculty of Medicine, Sebelas Maret University
}

\begin{abstract}
Background: Dynamic changes of disease development call for improvement in health care. In light of this context, public health nursing with home care has an increasing role in the management of diseases. Comprehensive public health nursing requires partnership between healthcare providers, patients, and their environment. In Indonesia the focus of nursing remains on hospital care, while rarely on home care that fulfils the need of the community. This study aimed to examine the implementation of public health nursing, encompassing its objective, resources, and work procedure, on home care patients.

Subjects and Method: This was a qualitative study with case study approach. This study was carried out at PKU Muhammadiyah Hospital, Surakarta, from February to March 2017. The key informants of this study included nurses, home care coordinator, doctors, dieticians, and physiotherapists. Methods of data collection included interview, observation, and archival review. Data were analyzed in stages normally employed in case study.

Results: The objectives of home care have generally been understood by most health providers. On the other hand the objectives of home care have not well-understood by the families of the patients, leading to inconsistency with the objective. There is a need to increase resources necessary for the nurses, particularly improvement in competency, as well as case selection, review, planning, coordinating, and evaluation. Likewise, collaboration between health care provider, patients, and their families, need to be improved in order to maximize home care.

Conclusion: There is a need to strenghten commitment of all parties involved in home care. The objectives of home care need to be understood by all parties. Hospitals are expected to have stronger responsibility with both work procedure in order to deliver optimal health care. By doing so, the public health nursing with home care will be able to fulfil the need of the community.
\end{abstract}

Keywords: home care, objective, resources, work procedure

Correspondence: Ratih Novitasari, Masters Program in Public Health, Sebelas Maret University, Jl. Ir. Sutami 36 A, Surakarta 57126, Central Java, Indonesia. Email: ratih.noph@yahoo.com. Mobile: +6285649524070. 